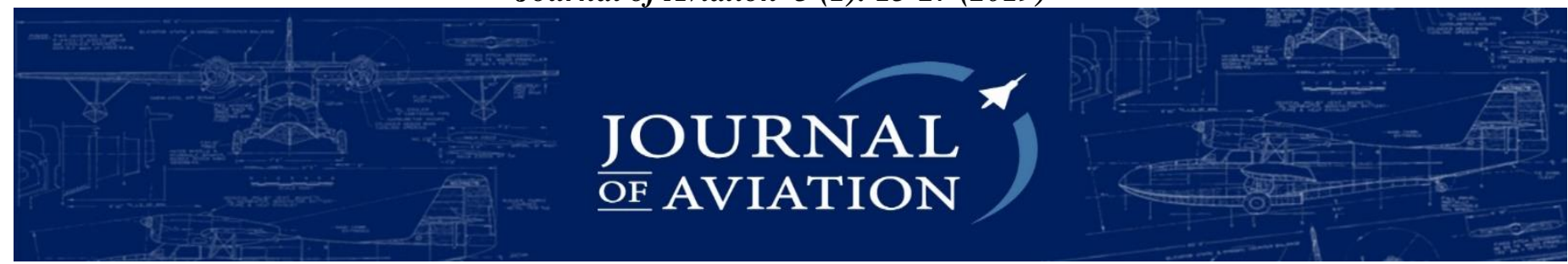

\title{
Güvenlik Stratejileri ve Yönetimi Açısından Havacılık Güvenliği
}

\author{
Eser GEMICII $\dot{I}^{*}$ iD, Harun YILMAZ ${ }^{2}$ (D) \\ ${ }^{1}$ Havacılık Yönetimi, Sivil Havacılık Yüksekokulu, Kastamonu Üniversitesi, Kastamonu, Türkiye \\ ${ }^{2}$ Havacılık Yönetimi, Sivil Havacılık Yüksekokulu, İskenderun Teknik Üniversitesi, İskenderun, Türkiye
}

\begin{abstract}
Özet
Uluslararası Sivil Havacılık Teşkilatı (ICAO) raporlarından elde edilen bilgiler 1şı̆̆ında 1950'li yıllarda 100 milyon civarında olan yolcu sayısının, 2016 yılına göre \%12,44 daha artarak 2018 yılında 4,3 milyara kadar ulaştığı görülmektedir. Günümüzde 1400 ticari havayolu şirketinin ve 4310 havaalanının bulunduğu sektörde dünya üzerindeki 1,1 milyar turistin yarısından fazlası havayolu ile taşınmaktadır. Bu rakamlardan da anlaşılacağı üzere sivil havacılık günümüzün en hızlı büyüyen sektörlerinden biridir. Aynı zamanda bu büyümeye uygun emniyetli ve güvenli bir sistemin ortaya konulması da ayrı bir önem taşımaktadır. Çünkü sivil havacılık sektörü ülkelerin yüzüdür ve bu nedenle teröristlerce eylemlerini gerçekletirebilecekleri cazip bir alan olarak görülmektedir. Diğer yandan teröristlerin uçaklardan, havalimanlarından ve ilgili tüm faaliyetlerden uzak tutulması adına kuramsal, hukuksal ve kurumsal değişimler yaşanmaktadır. Tüm bu değişimler sivil havacılık faaliyetlerinde güvenliğin tam anlamıyla sağlanması için gerçekleştirilmektedir. Sivil havacılık güvenliğinin sağlanması için güncel bir güvenlik stratejisi ve yönetimi içerisinde teknolojik gelişimin, insan faktörünün, kurumsal değişimin tüm taraflarca kabul görecek biçimde bir güvenlik kültürü oluşturması bir zorunluluktur. Tüm bunlarlar birlikte çalışmada, ülkemizde literatüre katkıda bulunulması ve güvenlik stratejileri ve yönetimi ile havacılık güvenliği arasındaki ilişkinin ortaya konulması amaçlanmıştır.
\end{abstract}

Anahtar Kelimeler: Güvenlik, güvenlik stratejisi, sivil havacıllk, havacıllk güvenliği

\section{Aviation Security in Terms of Security Strategies and Management}

\section{Abstract}

In the light of the information obtained from the International Civil Aviation Organization (ICAO) reports, it is seen that the number of passengers, which were around 100 million in 1950 s, increased by $12.44 \%$ compared to 2018 and reached to 4.3 billion in 2017. Nowadays, there are 1400 commercial airlines and 4310 airports in the sector and also more than half of the 1.1 billion tourists in the world are transported by airline. As it is understood from these figures, civil aviation is one of the fastest growing sectors of today. At the same time, it is important to reveal a safe and secure system suitable for this growth. Because the civil aviation sector is the face of the countries and therefore it is seen as an attractive area

* Sorumlu Yazar/Corresponding Author: Arş.Gör. Eser GEMİCI egemici@kastamonu.edu.tr
Alıntı/Citation : Gemici, E., Yılmaz, H. (2019). Güvenlik stratejileri ve yönetimi açısından havacılık güvenliği. Journal of Aviation, 3 (1), 15-27. DOI: 10.30518/jav.550123 
where the terrorists can perform their actions. On the other hand, there has theoretical, legal and institutional change in order to keep terrorists away from aeroplanes, airports and all related activities. All these changes are carried out to ensure complete security in civil aviation activities. In order to ensure the security of civil aviation, it is a necessity for technological development, human factor and institutional change to establish a security culture in a way that will be accepted by all parties within an up-to-date security strategy and management. The aim of this study is to contribute to the literature in our country and to determine the relationship between security strategies and management and aviation security.

Keywords: Security, security strategies, civil aviation, aviation security

\section{Giriș}

Havacıllk sektöründeki faaliyetlerin tümünün yürütülmesinde emniyet ve güvenlik üzerinde önemle durulması gereken iki temel unsurdur. Havac1lık faaliyetlerinde büyük öneme sahip ve iki temel unsurdan biri olan emniyet kavramı; "hata ve ihlallerden kaçınarak kural koyucuların düzenlemeleri ile uyum içinde kazalardan, ciddi olaylardan, tehlikelerden, kötü bir sonuca neden olan veya olabilecek etkenlerden uzak ya da muaf olma durumu" olarak tanımlanmaktadır [1]. Genellikle emniyeti insan veya sistemden kaynaklı hatalar tehlikeye atmaktadır. Güvenlik ise yasadışı eylemler ve sonuçları ile ilgilidir. Güvenlik; toplum yaşamında yasal düzenin aksamadan yürütülmesi, kişilerin korkusuzca yaşayabilmesi durumudur [2, 3]. Genellikle birbirleri ile karıştırılan bu iki temel kavramın doğru bir şekilde tanımlanması ve bu anlamda farklarının bilinmesi önem arz etmektedir. Havac1l1k faaliyetlerinin planlanan emniyet ve güvenlik seviyesinde yürütülebilmesinde sürece katılan insan faktörünün rolü çok önemlidir. Havaalanlarında güvenlik zafiyetinin yaşanmaması için öncelikle güvenlik personelinin hataları en aza indirecek şekilde eğitim sürekliliğinin sağlanması gereklidir. Bunun yanında uygun teknolojilerin kullanılması ve süreç standartlarının havaalanı karakteristiğine uygun şekilde tasarlanması da önemli faktörlerdir.

Teknoloji, havalimanı güvenliği açısından büyük önem taşımaktadır. Bununla birlikte ilgili teknolojiyi kullanacak olan güvenlik personelinin nitelikleri de oldukça önemlidir. Çünkü havaalanı güvenlik hizmetinde genellikle karar verici güvenlik personeli iken, teknoloji verilecek karara yardımcı olan araç konumundadır. $\mathrm{Bu}$ nedenle havaalanı güvenliğinin en üst seviyede sunulabilmesi nitelikli insan gücü ihtiyacını ortaya çıkarmaktadır. Güvenlik personelinin; alanında eğitimli olması, ruhsal ve bedensel sağlık yönünden engelsiz olmas1, görev tanımı ile yeteneklerinin uyumlu olması, motivasyon düzeyinin yüksek olması beklenmektedir.

Diğer yandan teknoloji ve insan faktörünün yanı sıra uluslararası düzenlemelere, standartlara uygun ve güncel bir güvenlik stratejisi ve yönetiminin belirlenmesinin ve havacıllk alanında uygulanmasının da sivil havacılık güvenliğini sağlamaya yönelik faaliyetlerin sürdürülebilir ve tüm taraflara güven hissi verecek olması bakımlarından önem arz etmektedir. Tüm bu sebeplerle bu çalışmada güvenlik kavramının çerçevesi içerisinde havacılık güvenliğinin irdelenmesi amaçlanmıştır.

\section{Kavramsal Çerçeve}

\subsection{Güvenlik ve Strateji Kavramı}

Güvenlik kavramı, zihnin felsefi ve psikolojik durumunu ifade eden şekliyle ilk olarak Cicero ve Lucretius tarafindan "securitas" olarak ortaya konulmuştur [4]. Cabric (2015), güvenlik kelimesinin sözel kaynağının ve anlamının analizinden önce onun özünü anlamanın daha faydalı olacağını dile getirmekte ve en eski atalarımızdan beri güvenliğin ilkelerinin değişmediği ifade etmektedir. $\mathrm{Bu}$ anlamda, mağaranın güvenliğini sağlamaya çalışan bir kişinin mağara ağzında nöbet tutarak ortaya çıkabilecek olumsuz bir durumda içerdekileri önceden uyaracak olmasının ve bunu bilen tüm içerdeki kişilerin kendilerini güvende hissetmesinin aslında güvenliğin özünü oluşturduğu ifade edilmektedir [5].

Yukarıdaki tanımdan da anlaşılacağı üzere var olma ve varlığı sürdürme ile doğrudan ilintili olan güvenlik, bunun sağlanması yönünden de strateji 
kavramına dayanmaktadır. Uygulanan her strateji, bir güvenlik anlayışını temsil etmekte ve her güvenlik arayışı da bir strateji içermektedir. Güvenliğin sağlanması ve artırılması, hangi aktör ve sektör tipi için olursa olsun, kolektif bir yapılanmayı zorunlu kılmaktadır. Buradan hareketle güvenlik kavramı nasıl tehdit kavramı ile birlikte ele alınmaktaysa, strateji kavramı da büyük ölçüde güvenlik kavramı ile birlikte değerlendirilmektedir. Burada üzerinde durulması gereken konu, güvenlik anlayışı ve tehdit algılamasının stratejiden önce geldiğidir. En kaba tanımıyla strateji, kendi varlığını sürdürme ve geliştirme ile karşı tarafın, yani varlığını koruma ve sürdürme olgularını tehdit edenin, bertaraf edilmesine yönelik eylem ve uygulamaları ifade etmektedir. Her aktörün çevresi ile arasındaki ilişkileri düzenlemesinin ve rakiplerine üstünlük sağlayabilmek için kaynaklarını harekete geçirmesinin, stratejinin konusunu oluşturduğu ifade edilmektedir. $\mathrm{Bu}$ haliyle stratejinin, güvenliğin nasıl sağlanacağı konusundaki yanıtın aranmasını, yürütülmesini ve sonuçlandırılmasını kapsadığı aktarılmaktadır [6].

Modern güvenlik kavramının ise iç güvenliğin, dış ve askeri politikaların ve uluslararası hukukun temel bir unsuru olan dış güvenlikten ayrılmaya başladığı 17. yüzyıldan bu yana geliştiği aktarılmaktadır $[2,7]$.

Güvenlik kavramının, literatürde özünde ihtilaflı bir kavram olarak tanımının ortaya konmasının mümkün olmadığ [8] veya tüm zamanlar ve mekanlar için geçerli bir cevabının bulunmadığı [9] ya da esasen basit bir kavram olduğu ve bu anlamda tanımının açık olduğu dile getirilmektedir [10]. Güvenlik, kelime anlamı olarak en basit ifadeyle tehditler, kaygilar ve tehlikelerden uzak olma hissi içerisinde bulunma hali olarak tanımlanmaktadır [3]. Buradan hareketle güvenlik, bir bireyin diğerlerinin verebileceği zararlardan ya da tehlikeli ihtimallerden uzak olduğunu düşündüğü, hissettiği ruh hali olarak açıklanmaktadır [2]. Diğer yandan tehditlerin, tehlikelerin, zararlı olasılıkların yokluğu biçiminde tarif edilen güvenliğin [11], öznenin varlığı (biri ya da bir şeyin tehdit altında olması); yaklaşan ya da fiili bir tehlike; tehlikeli ihtimallerden kaçmak için bir isteğin bulunmas1, şeklinde üç temel bileşenden oluştuğu ifade edilmektedir. Tüm bu bileşenler dikkate alındığında hangi öznenin, hangi tehlikeye karşı hangi öncelikte olacağı sorunu ile karşılaşılmakta ve Booth (2007) güvenliğin bu anlamda tanımının basit olduğunu ancak dünya siyaseti bağlamında güvenlik kavramına ilişkin tanımın kavramın anlamında olmayıp anlamın siyasetinde olduğunu dile getirmektedir. Çünkü güvenlik kelimesinin siyasal söylemde öncelik ifade ettiğini ve siyasi söylem ile güvenlikten ne anlaşılması gerektiği dile getirildiği an, toplum tüm zaman, enerji ve kaynaklarını ilgili siyasi söylemin ortaya koyduğu güvenlik anlayışına yönlendirmektedir [10].

Güvenlik, korku veya tehlikelerden arınmış bir şekilde özgür ya da bu korku ve tehlikelere karş1 savunma yeteneğine sahip olmak şeklinde de tanımlanmaktadır [4, 12]. Buzan (1983) ise güvenliği, toplumun ve devletin sahip olduğu bağımsız kimliği ve bütünlüğü koruma hususundaki kabiliyet olarak tanımlamaktadır [13]. Erdoğan (2013) çalışmasında güvenlik kavramının, tehlike, zarar veya korku gibi unsurlar ile karşı karşıya kalma ya da kalmama şeklinde bir edilgen, ilgili unsurların ortaya çıkmasına neden olan bir de etken boyutu olduğunu belirtmek suretiyle güvenliğe ilişkin tanımı ortaya koymaktadır. Edilgen boyutta, güvenliği sağlanması gereken süjelerin, etken boyutta ise bu süjelere yönelmiş tehditlerin neler olduğu sorusuna yanıt arandığını görmekteyiz. Ancak bu sorulara yanıt ararken güvenlik kavramına ilişkin olarak güvenilebilir ve süreklilik arz eden bir tanımın ortaya konulmasının küreselleşen dünyada zor olduğunu ifade etmektedir [14].

Geçmişten günümüze tartışıla gelen güvenliğe ilişkin tüm bu tanımlamalar ile birlikte Soğuk Savaş döneminin ortaya çıkardığ 1 yapay korkular üzerine inşa edilen geleneksel güvenlik telakkisinin son y1llarda devletlerin birbirlerine bağımlılığı ve küreselleşmenin tesiri ile yerini gerçek korkulara ve yeni güvenlik alanlarına bıraktığı ifade edilmektedir [9]. Bu anlamda yeni dönemde çevre güvenliği, ekonomik güvenlik, siyasi güvenlik, toplumsal güvenlik, bilgi güvenliği ve birey güvenliği vb. gibi yeni güvenlik alanlarının, unsurlarının ortaya çıktığı görülmektedir [15]. 
Güvenlik kavramına ilişkin tanımlamalar, kimin ve neyin güvenliği ya da güvenlik sorunu nedir ve güvenlik nasıl başarılır gibi sorulara aranan cevaplar bakımından [16] çok çeşitli olabildiği gibi güvenliğin evrimine ilişsin sürecin ise bu ve bu gibi sorulara aranan cevaplara ilişkin teorik yaklaşımlar 1şı̆̆ında geliştiği görülmektedir. İkinci Dünya Savaşı sonrası ortaya çıkan Soğuk Savaş döneminin (1945-1989) ABD ve Rusya arasındaki çekişmenin, silahlanma yarışının ve teknolojik rekabetin aynı zamanda yoğun bir şekilde ekonomik ve politik yarışın gerçekleştiği, nükleer silah stokunun yapıldığı bir dönem olduğu dile getirilmektedir. $\mathrm{Bu}$ rekabetin ve nükleer silah stokunun ise realist teoriye, devlet davranışını ve askeri ve diğer anlamlarda güvenlik arayışını açıklamak için güçlü bir temel sağladığı ifade edilmektedir [17]. Diğer yandan özellikle Soğuk Savaş döneminde güvenlik çalışmalarındaki baskın yaklaşımın, politik realizm savunmas1 ve devlet, strateji, bilim ve statüko (states, strategy, science and the status quo) gibi dört temel faktör ile meşgul olmak olduğu aktarılmaktadır [16]. Devlet ve devletlerarası güvenliğe ilişkin yaklaşımlar Soğuk Savaş sonrası yetersiz görülerek daha çok etnik-milliyetçi grupların merkezde yer aldığı güvenlik anlayışı ortaya koyulurken, farklı düşünürler ise küreselleşmenin getirdiği korkuları ve tehlikeleri yenmenin ancak küresel bir toplumun inşası ile mümkün olabileceğini ifade etmektedirler. Sonuç olarak Soğuk Savaş'ın sona ermesinin, Doğu-Batı arasındaki nükleer rekabetin azalmasının dünyayı daha güvenli bir yer haline getirdiği ancak bunlarla birlikte realizmin, sivil havacilık endüstrisinde yaşanan en büyük terör eylemi olan 11 Eylül saldırılarının ardından yeniden güçlü bir şekilde merkeze oturduğu aktarılmaktadır. Bu gelişmelerin yanı sıra uluslararası kurum, kuruluşlar ve örgütler ile devletler arasında gelişen ilişkilerin, güvenliğe ilişkin geleneksel bakış açısının değiştirilebilmesi adına daha sağlıklı ve hareketli bir ortam oluşturduğu ancak kimyasal, biyolojik, nükleer silahlanma, hırslı siyasetçiler ve devlet adamları, kültürel ve dini farklılıklar, yükselen 1rkçılık vb., gibi etmenler nedeniyle devletlerin güvenliği üzerine ortaya konulacak tüm düşüncelerin savaşları veya çatışmaları bitirip bitirmeyeceği, bir barış ortamı oluşturup oluşturmayacağı hususlarında temel problemler olarak kalmaya devam edeceği ifade edilmektedir [18].

\subsection{Güvenlik Kavramının Çerçevesi}

Günümüzde güvenlik, sadece savaştan korunmak veya savaşı engellemek olarak anlaşılmamakta, bunun yanında hayatta kalabilmeyi ve refahı etkileyecek tehlikelerden korunmayı da içermektedir. Geleneksel tehditler aynı kalmakla birlikte günümüzde güvenlik, küresel düzeydeki tüm gelişmelerden etkilenir hale gelmiştir. Bunların yanı sıra doğal felaketler, mülteci akınları, terör eylemleri, etnik milliyetçiliğin yükselmesi gibi olgular da devletlerin güvenliğini doğrudan veya dolaylı şekilde ilgilendirir hale gelmiştir [19].

Güvenlik kavramsal çerçevede hem tehdit ve saldırı unsurlarını hem de savunma, önlem ve caydırıcılık öğelerini birlikte içerir. Saldırıya karşı korunmak bugün de ulusal hükümetlerin esas amaçlarından biri olup aynı zamanda küresel güvenliği gerçekleştirirken üstünden gelinmesi gereken zorluklardan yalnızca biridir [20].

Buzan, güvenliği askeri, politik, ekonomik, toplumsal ve çevresel olmak üzere beş farklı boyutta tanımlamış aynı zamanda bütün bu farklı boyutların birbiri ile bağlantılı olduğunu ve karşıllıklı olarak birbirini pekiştirdiğini belirtmiştir. $\mathrm{Bu}$ faktörler birbirlerini olumlu veya olumsuz yönde etkileyebilirler. Güvenliğin ulusları aşan ve çok boyutlu hale gelen karakteri; bir boyutunda yaşanan küçük bir sorunun, diğer boyutlarında felaketle sonuçlanmasına yol açabilmektedir. $\mathrm{Bu}$ durum, küreselleşen dünya ile daha da anlamlı hale gelmektedir. Küreselleşme ve güvenliğin yeni tanımı arasında çok yakın bir ilişki bulunmaktadır [21]. Terörist eylemler bugün küreselleşmenin bir sonucu olarak karşımıza çıkmaktadır. Ulus devletlerin içerisindeki alt kültür gruplarının özerklik istekleri, teknolojinin silah olanakları, canlı bombalar ya da silaha dönüştürülebilen uçaklar, terörist yöntemleri yaygınlaştırmakta ve küreselleştirmektedir. 
Tablo 1. Güvenlik ortamının değişimi [22].

\begin{tabular}{ll}
\multicolumn{1}{c}{ Soğuk Savaş } & \multicolumn{1}{c}{ Günümüz } \\
\hline - Devlet merkezli & - Küreselleşme \\
uluslararası düzen & - Güç; askeri, ekonomik ve \\
- İki kutupluluk & ulus aşan \\
- Ulusal güvenlik endeksli & - Çıkar endeksli \\
- Ulusal savunma & - Güvenliğin geniş boyutu \\
- Tehlikeyi caydırmak ve & - Çatışma kapsamının \\
savunmak & genişlemesi \\
- Çatışma kaynakları & - Çatışma kaynaklarının \\
belirgin & belirsizliği \\
\hline
\end{tabular}

Tablodan da anlaşılacağı üzere soğuk savaş döneminden sonra küreselleşme ile birlikte güvenliğin geniş boyut kazandığı ve çatışma kapsamının genişlediği, güvenliği tehdit edecek unsurların sadece ulusal içerikli olmayacağ ulusuaşan güvenlik tehditlerinin de ortaya çıkabileceği görülmektedir.

21. yüzyıla uluslararası sistemde kırılma yaratan ve küresel güven(siz)lik için bir dönüm noktası teşkil eden 11 Eylül saldırılarıyla adım atılırken yeni güvenlik anlayışı ve yaklaşımlarının nasıl olacağına ilişkin kuramsal tartışmaların niceliği ve niteliğinde önemli bir değişim yaşanmıştır. 11 Eylül saldırıları, çok boyutlu güvenlik stratejilerini ön plana çıkarmış ve küresel sistem ile iç politika arasındaki bağı kuvvetlendirmiştir. Başta BM olmak üzere uluslararası örgütlerin de sürece aktif katılımının sağlanması ve örgütlerin yeni güvenlik anlayışının uygulayıcısı olmasının sağlanması bu kapsamda öncelenmiştir [23].

\section{Yeni Güvenlik Anlayışı Perspektifinde Havacılık Güvenliği}

Uluslararası Sivil Havacılık Teşkilatı (ICAO) raporlarından elde edilen bilgiler 1şığında çalışmanın özet kısmında ifade edilen rakamlardan da anlaşılacağ dünya üzerindeki 1,1 milyar turistin yarısından fazlası havayolunu tercih etmiştir. Bunun yanında kargo taşımacılığ göre \%3,5 artış göstererek 2017 yılında 56 milyon tona ulaşmıştır. 2017 yılında sivil havacılık sektörünün tüm gelirlerinin 758 milyar dolara ulaştığı ve sektörde faaliyet gösteren tüm işletmelerin bu gelirden yaklaşık 60 milyar dolar civarında kar ettikleri bilinmektedir [24].
Bugün dünya ticaretinin \%40'nın sivil hava taşımacıllı̆ 1 marifetiyle yapıldığ 1 [25] ve 50,000 'den fazla rotaya sahip 58 milyon işgücü istihdamı bulunan ve geçmiş 100 yılda toplamda 65 milyar yolcunun havayolu ile taşındığ 1 düşünülürse [26] sivil havac1lık sektörünün dünyada diğer tüm sektörler ile karşılaştırıldığında hızlı ve sağlam adımlarla, kurallara sıkı şekilde bağlı, en iyi büyüyen sektör olarak üst sıralarda yer aldığ1 görülmektedir.

Sivil havacılık sektöründeki bu büyüme, propaganda avantaj1 ve uçağa yönelik hareket kabiliyetinin azlığından dolayı terörist gruplar için havacılık sektörünü daha cazip hale getirmiştir [27]. 2016 y1lında Brüksel, İstanbul, Şanghay ve Ocak 2017'de Fort Lauderdale (Florida USA)'deki havalimanlarına yapılan saldırılar, havalimanı içindeki kamuya açık alanların savunmasız ve hassas olduğunu göstermiştir. Açıkçası, kendi ülkelerindeki havalimanlarının kara tarafındaki güvenliğin sağlanması hükümetlerin sorumluluğundadır. Ancak IATA da, artan kara tarafı güvenliği için girişimlere devam etmektedir [28].

Sivil havacılık güvenliği, uçaklara ve havalimanlarına yönelik düzenlenecek suç unsuru faaliyetlerini önlemek için oluşturulmuştur. $\mathrm{Bu}$ anlamda "Güvenlik" kavramı sivil havacılık faaliyetleri konusunda en önemli uluslararas düzenleyici kuruluşlardan birisi olan Uluslararası Sivil Havacılık Teşkilatı (International Civil Aviation Organization-ICAO) tarafından geniş bir şekilde ele alınmıştır. $\mathrm{Bu}$ anlamda ICAO "güvenliği”" "uluslararası sivil havacılığı kanunsuz eylemlere karşı korumayı amaçlayan çeşitli önlemler ile insan ve malzeme kaynaklarının birleşimi" olarak tanımlamaktadır [29]. Buradan hareketle Gerede (2006) havacılık güvenliğini (aviation security); doğrudan ve dolaylı olarak havacılık faaliyetleri kapsamına giren insanların, havaaraçlarının ve hava taşımacılığı altyapısının sabotaj ve terörist saldırılar gibi suç unsuru taşıyan ve bilinçli olarak yaratılmış tehlikelerden korunması ile ilgili faaliyetleri ve bunun için gerekli olan kaynakları kapsayan bir kavramdır" şeklinde tanımlamaktadır [30]. 
Güvenlik fonksiyonel olarak başka safhalara sahip bulunmakta olup sektörel güvenlik bunlardan biridir. Grup, örgüt, şirket veya organizasyonların korunma, koruma ve devamlılığ 1 sağlayacak ilgili önleyici tedbirleri alma işlemlerinin gerçekleştirildiği süreç sektörel güvenlik alanıdır. Sektörel güvenlik ünite güvenliği, toplumsal güvenlik, fiziki güvenlik, kurumsal güvenlik ve alan güvenliği gibi başlıklar altında toplanabilinir. Burada ifade edilen çerçeve kamu sorumluluğu altında veya kurumsal sorumluluk altında stratejik ve taktik seviyede alınması gereken önlemleri çerçeveleyen bir güvenlik yaklaşımıdır. Organizasyon içerisinde yürütülmekte olan bir güvenlik faaliyetinden söz edilmektedir.

Güvenliğin bu fonksiyonel safhalarında kamu veya kurumsal sorumluluk altında stratejik ve taktik anlamda güvenliğin en ön planda olduğu sektörlerden biri olan havacılık endüstrisi 1970 ve 1980 arasında havaalanı saldırıları, kaçırmalar ve küçük hava bombardımanları ile yüz yüze kalmıştır. Bu gibi tehditlere karşı koymak aynı zamanda bu saldırıların ana hedefi olan uçakları korumak ve yolcuları emniyeti uğruna kabin ekipleri bu kaçırmalara karşı boyun eğmemeleri hususunda eğitiliyorlardı. 11 Eylül saldırılarının ardından hukukun tek başına böyle büyük terör olaylarını engelleyemediği anlaşılmıştır. Ardından kokpit kapılarının kilitlenmesi ya da tüm yolcuların tamamen taranması gibi kimi farklı uygulamalar hayata geçirilmiştir [31]. 11 Eylül saldırılarında uçakların bir kitle imha silahı olarak kullanıldığında, yolcu servislerinin ve kabin ekiplerinin bu kaçırmalara boyun eğmeleri hususundaki eğitimlerinin öldürücü sonuçlarını kanıtlamış ve havacılık endüstrisine bir gecede kabin ekibinin asla, izinsiz kişilerin uçuş kabinine girmesi konusunda izin vermemeleri gerektiğini öğretmiştir [32].

11 Eylül saldırıları havacılık güvenliğini ve seyahati nasıl etkilemişti? Devran dönmüş ve artık güvenlik zamanında kalkış ve müşteri hizmetlerinde önceliği almış, artan kamu kontrolleri ve güvenlik önlemleri nedeniyle oluşan uzun güvenlik kontrol kuyrukları yolculara seyahatlerinde güvenliklerinin ve emniyetlerinin temini için sabırlı olmayı öğretmişti. Bu anlamda 11 Eylül saldırıları sonrası, yapılacak birçok şey vardı. Birçok güvenlik önlemi alındı. Ulaştırma Güvenliği Teşkilatı (Transportation Security Administration), (TSA) kuruldu. X-ray tarayıcı eğitimleri hususunda geniş manada yeni uygulamalar getirildi. Uçuş güvenliğini tehlikeye sokabilecek birçok maddenin havaalanlarına ve uçaklara girişleri yasaklandı [32].

Sektörel anlamda havalimanı güvenliği günümüzde uluslararası bir boyut kazanmış olup havalimanı güvenliğine dayanan ve havalimanı güvenliğini geliştirecek olan üç ilke tanımlanmıştır;

- Sivil havacılık tesislerine yapılabilecek terörist saldırıları engellemek için her türlü çaba sarf edilmelidir.

- Teröristler havacılık tesislerine ilk girişlerinde, onların bu tesislere nüfuz etmesini engelleyecek patlayıcı metal algılama cihazları ve prosedürlerden oluşan bir sistem ile karşılaşmalıdır.

- Eğer bir sistem bu girişimi kaçıracak olursa ikinci adım mümkün olabilecek bir patlamayı durdurabilecek ve zararı minimize edecek şekilde yolcu ve yükünün sağ kalabilme olasılığını artırmak için uçak sistemleri ve yapısı azami ölçüde sağlam olmalıdır.

$\mathrm{Bu}$ ilkelerde açıkça görülmektedir ki teknoloji üzerinde odaklanılmaktadır. Saldırıları karşılayacak bir sistem olmalı ve yapılar güvenli olacak şekilde üretilmelidir. Örneğin 11 eylül sonrası uçak kaçırmalarını engellemek için kokpit kapıları daha sert bir malzemeden üretilmiştir [33]. Bu adımlar güvenlik stratejileri ve yönetimi açısından havacılık güvenliğinde, güvenliği sağlamaya, terör eylemlerini engellemeye ve teröristleri uçaklardan ve havalimanlarından uzak tutmaya yönelik bir stratejinin izlendiğini göstermektedir. Diğer yandan Uluslararası Hava Taşımacılığı Birliği (IATA) havacılık güvenliği konusunda da önemli çalışmalar yapmaktadır. $\mathrm{Bu}$ faaliyetler 5 ana öğeyi kapsamaktadır;

-Küresel standartların teşvik edilmesi,

- Gelişmekte olan tehditlerle başa çıkmak,

•Bir "güvenlik kültürünün" teşvik edilmesi,

• Güvenlikle ilgili bilgilerin paylaşımını savunmak,

-Emniyet ve güvenlik yönetim sistemlerinin yasal olarak tanınması için lobi çalışmaların yapılmasi. 
IATA, havacılık güvenliğinin bir kültür olarak algılanması üzerine çalış1lması gerektiğini vurgulamıştır. Personel, ekipman ve süreçler ile birlikte havalimanlarında ve uçaklarda güvenlik uygulamalarının var olduğu bir ortamdan bahsedilmektedir. $\mathrm{Bu}$ durum herkes tarafindan bilinmeli ve buna göre davranılması gerektiği üzerinde durulmaktadır. Öyle ki havalimanı işletmeleri yolcuları "yanlış anlamalara neden olmamak için terör eylemlerini çağrıştırıcı, bomba veya silah olduğuna dair şaka dahi yapılmaması" konusunda uyarmaktadır [28].

11 Eylül saldırılarının ardından yukarıda belirlenen ilkelerin yanında havacılık sektörü birçok paydaşının yanında artık güvenliği de bir paydaş olarak görmekte ve hatta güvenlik havac1lık sektörünün ana paydaşlarından biri haline gelmiş durumdadır. Havacılık sektöründe artık güvenliğin önemini daha iyi kavrayabilmemiz için aşağıdaki tablodan çıkarımlarda bulunabiliriz [32].

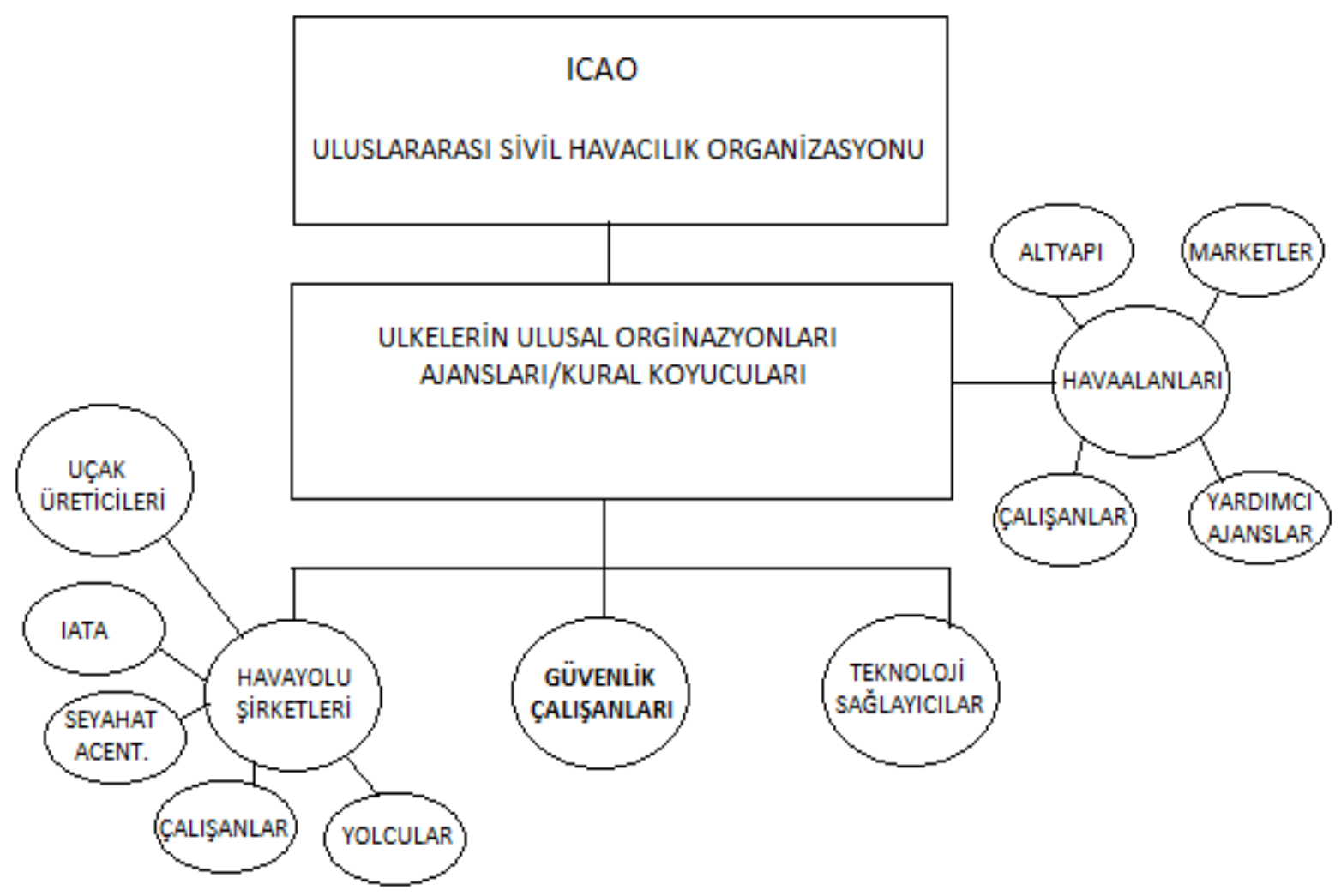

Şekil 1. Havacılık endüstrisinin paydaşları [32].

Havacılık alanındaki güvenlik çalışanlarının 11 Eylül saldırılarının ardından havacılık sektörünün paydaşları arasındaki yerinin vazgeçilemez öneme sahip olduğu anlaşılmış ve bu noktada yerini almıştır. Havacılık güvenliğine olası tehdit, saldırı kaynakları belirlenmiş ve bu tehditlerin taktikleri ve hedefleri ortaya konmuştur. Yeni belirlenen bu tehdit kaynaklarının ve bu kaynakların hedeflerini, taktiklerini Şekil 2'de görebiliriz [34]. 


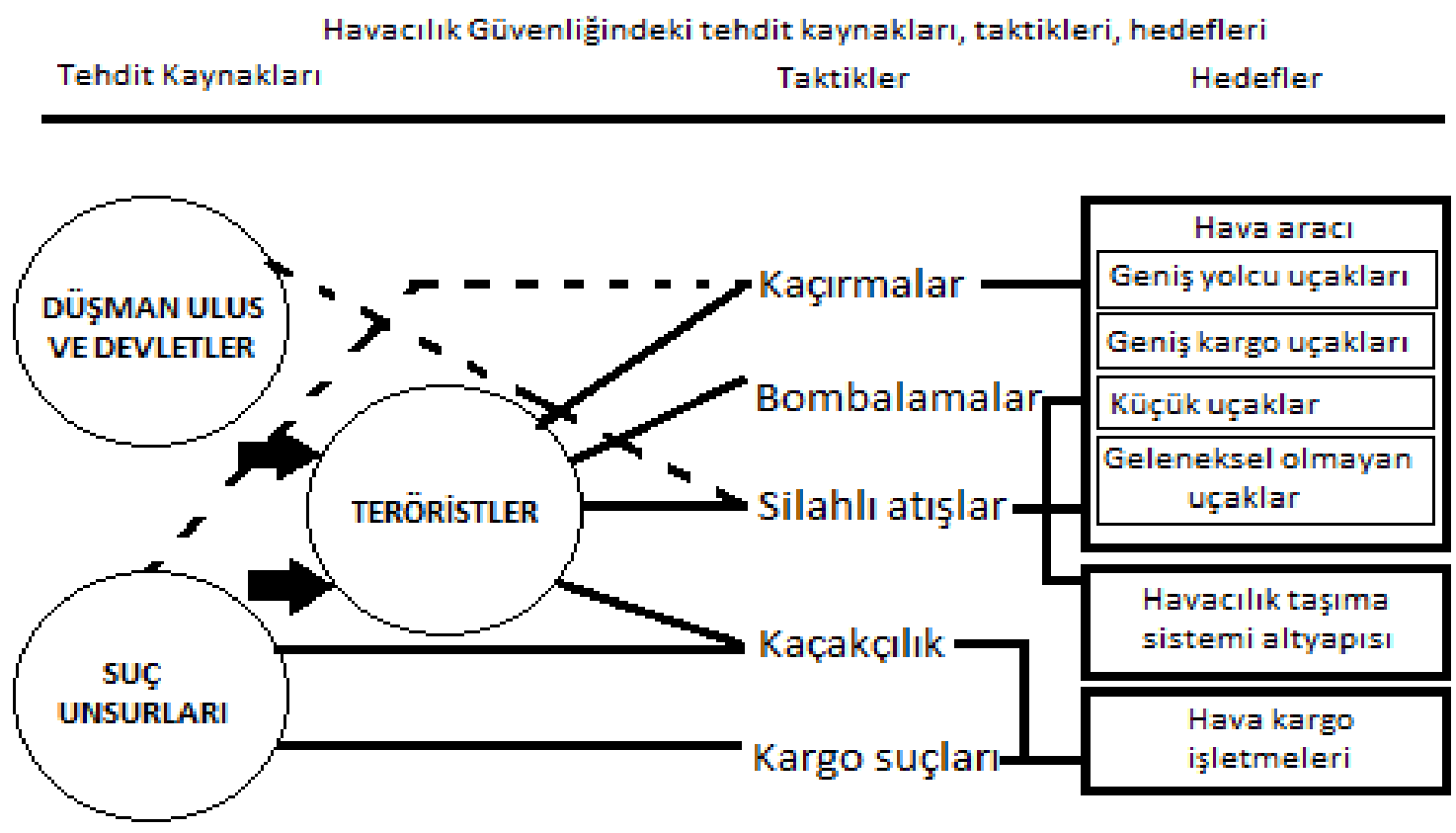

Şekil 2. Havacılık güvenliğindeki tehdit kaynakları [34].

\section{Havaalanı/Meydanı Güvenliği}

Sivil havacılık güvenliğinin ilk uçak kaçırma olaylarıyla dünya gündemine geldiği söylenebilir. İlk uçak kaçırma eylemi 1931 yılında rapor edilmiş ve Peru'da gerçekleşmiştir [35]. 1948 yılında Porto Riko'dan New York'a gerçekleşen uçuş sırasında yolculardan Santano ve Cordova adında iki yolcu, uçağa binişlerinden önce alkollü olmalarının yanı sıra uçağa bindikten sonra da alkol almaya devam etmişler ve ardından birbirleriyle kavga ettikten sonra uçuş ekibiyle kavga etmişlerdir. Uçağın New York'a varmasının ardından iki yolcu tutuklanmış ve Açık Denizlerde Meydana Gelen Ölümlere İlişkin Yasa (Death on the High Seas Act - DOHSA) altında yargılanmışlardır. Ancak mahkeme Açık Denizlerde Meydana Gelen Ölümlere İlişkin Yasa'nın uçaklara uygulanamayacağı karar vermiş ve bu iki yolcu yargılanmaktan kurtulmuşlardır [31, 36]. Uçak içinde meydana gelen yasa dış1 eylemler bunlarla sınırlı kalmamış sadece 1968 ile 1970 yılları arasında 200 uçak kaçırma eylemi gerçekleştirilmiştir. Bu durum sivil havacılığın karanlık tarafi olarak görülmektedir [35]. 1958 y1lında Fidel Castro'nun Küba'da iktidara gelmesi, uçak kaçırma olaylarının seyrini değiştiren önemli bir olay olmuştur. Çünkü Castro'nun iktidarı Küba ile ABD arasında siyasal gerilimi arttırmıştır. ABD'den Küba'ya yönelen uçak kaçırma olayları sonucunda dev Amerikan Hava Ulaşım Şirketlerinin oluşturduğu baskı, dünya kamuoyunun uçak kaçırma olaylarına karşı dikkatini çekmeyi başarmış ve uçak kaçırma bir suç olarak kabul edilmiş, bu anlamda eylemlere karşı ilk önlemi de ABD almıştır [37].

1970'lerde havaalanlarına yerleştirilen metal dedektörler başlarda engelleyici bir unsur olmuştur. Ancak teröristler uçağa deniz aşırı havaalanlarından el çantalarına yükledikleri patlayıcıları uçakta patlatmaya başlayarak bu korumayı aşmayı başarmışlardır. El çantalarının havalimanlarında kontrol edilmeye başlanmasıyla eylemciler, yollanmak üzere teslim alınan bagajlar içine patlayıcı yerleştirmeyi denemişlerdir. Bu tehdidinde alınan tedbirlerle ortadan kaldırılmasıyla, eylemcilerin en son geliştirdikleri yöntem intihar eylemleri olmuștur ki bu durum hava korsanlı $\breve{g}_{1}$ için yeni bir dönemin başlangıcı olmuştur [38].

Dünyada uçak ve havaalanlarına karşı girişilen saldırılar artık terörizm olarak adlandırılmaya başlamıştır. 11 Eylül 2001 terör saldırıları uçak kaçırma olaylarının boyutunu tamamen değiştirmiş, uçakların bir intihar eyleminin aracı olarak kullanılması binlerce insanın ölümüne neden olmuştur. Hava korsanı olarak nitelendirilemeyecek olan teröristler o ana kadar alınan tüm hukuksal ve teknik güvenlik önlemlerinin hava ulaşımının güvenliğini sağlamada hala yetersiz olduğunu gözler önüne serilmesine de sebebiyet vermişlerdir. 
Türkiye'de hava meydanları havacılık sektörünün gelişimi ve sivil havacılık faaliyetlerinin başlamasıyla birlikte öncelikli korunan tesisler konumuna gelmiştir. 1960 ve 1970'li y1llara geldiğimizde dünya genelinde yoğun bir terör faaliyeti olduğundan, bu durum Türkiye'deki hava meydanlarında güvenlik tedbirlerinin çeşitlenmesine, yolcu ve bagaj tarama sistem ve cihazlarının daha çok kullanılmasına neden olmuştur. 1988 tarihinde "Hava Meydanlarında Alınacak Güvenlik Tertip ve Tedbirleri Yönetmeliği” yürürlüğe konulmuştur. $\mathrm{Bu}$ yönetmelikle ilk defa Milli Sivil Havacılık Güvenlik Kurulu ve Havaalanı Güvenlik Komisyonun oluşturulması ve Özel Güvenlik Teşkilatının hava meydanı güvenlik hizmetlerinde kullanılması yer almıştır [39].

Günümüzde bir hava meydanının en önemli bölümünü havaalanı veya havalimanı diye tanımladığımız terminal binaları oluşturmaktadır. Bir havalimanı (veya terminal binasında) güvenliğinde birbiriyle bağlantılı güvenlik önlemleri alınmakta, teknolojik güvenlik sistemleri insan kabiliyetleriyle birleşmektedir. Gelişmiş x-ray cihazları, patlayıcı dedektörleri, kamera sistemleri, dedektör köpekleri, kapı geçiş sistemleri ve metal arama dedektörleri gibi sistem ve cihazlar havalimanındaki güvenlik personeli tarafindan kullanılmaktadır.

\section{Güvenliğin Sağlanmasında Güvenlik Personeli}

Bir havaalanı veya havalimanı güvenliğinde, güvenlik kontrol noktalarında güvenlik sistem ve cihazları ile güvenlik personelleri bulunmaktadır. Güvenlik kontrol noktasının amacı güvenliği tehlikeye düşürebilecek her türlü madde, cisim veya kişiyi tespit ederek başta terminal güvenliği olmak üzere yolcu, uçak, mürettebat (kaptan, hostes vb.) ve uçağın kaçırılmasına karşı, dünyadaki herhangi bir devletin veya milletin güvenliğini sağlamaktır. [40].

Sivil havacılık güvenliğinin sağlanmasında insan faktörü gelişmiş cihazların gölgesinde kalmış gibi görünse de, güvenlik hizmetlerinin etkili bir şekilde uygulanması her zaman hizmetleri icra eden güvenlik personellerine bağl1 olmuştur. Örneğin bir $\mathrm{x}$-ray tarayıcısı havalimanındaki en önemli güvenlik cihazıdır ancak bu cihazı güvenlik personeli yönlendirmekte ve mevcut tehdit ve tehlikelere, monitörlere yansıyan görüntüler yardımıyla güvenlik görevlileri karar vermektedir. Yani bir havaalanında en son teknolojik cihazlar bile insan kullanımı ve yönlendirmesine ihtiyaç duymaktadır.

"Havaalanları Güvenliği ve Sabiha Gökçen Uluslararası Havaalanı Güvenlik Sistemi İçin Bir Model Önerisi”" isimli 2001 yılında hazırladığı doktora tez çalışmasında Küçükönal; "güvenlik cihazlarının teknolojisinde çok önemli gelişmelerin olmasına rağmen hiçbir şeyin iyi eğitilmiş ve motive olmuş güvenlik personelinin yerini tutamayacağını, güvenlik cihazlarının cihazı kullanacak personelin beceri ve kararı ile verimli bir şekilde kullanılabileceği ve iyi bir şekilde organize olmuş, motivasyonu yüksek ve bilgili bir havacılık güvenlik biriminin, hava meydanı güvenlik önlemlerinin uygulanmasında temel oluşturacağını" belirtmektedir [41].

Havaalanında yolculara ve tesislere yönelik güvenlik tehditlerini tespit etmek için güvenlik teknolojisinin kullanılması, teknolojik ürünler ile güvenlik görevlisinin davranışını yöneten kurallar ve düzenlemeleri birbirine bağlayan örgütsel bir yap1 içinde var olması anlamına gelmektedir. Konunun anlaşılması açısından en uygun açıklama, özellikle çalışanların teknolojiye güven derecesi, teknolojiye tamamıla güvenmesi veya tehditleri tespit etmenin en iyi yolun algılanması gibi teknolojik çıktıları çalışanların nasıl yorumladığına dayanmaktadır [42].

Havalimanında "Güvenlik İklimi” ni etkileyen unsurlardan bir tanesi de havalimanı güvenlik personelinin örgüt içinde yöneticilere, çalışanlara ve varolan güvenlik politikalarına karşı duyulan güven seviyesidir. Çünkü örgüt yönetimine ve örgütte izlenen politika ve yöntemlerin adilliğine duyulan güven hissi işgören bağlılığında belirleyici rol oynamaktadır [43].

11 Eylül 2001 terörist saldırıları öncesi, ABD sivil havacılık güvenliği sistemi, özel güvenlik şirketleri tarafından sağlanıyordu. Federal Havac1l1k otoritesi olan FAA (Federal Aviation Administration), bir kamu kuruluşu olarak güvenlik politikasını ve standartları belirleyen otorite; özel havayolu şirketleri de belirlenen standartlarda 
güvenlik hizmeti vermeyi taahhüt eden ajanslardı. Havacılık güvenliği sistemi ticari havayolu şirketlerinin inisiyatifine bırakılmıştı.

$\mathrm{Bu}$ durum 11 Eylül saldırılarına kadar birçok defa eleştirilse ve yeniden yapılanma tavsiye edilse de bu şekilde devam etti. Saldırılardan henüz 9 gün sonra Ulusal Denetleme Ofisi (General Accounting Office) Federal Havacilık otoritesi olan FAA'in özel şirketler aracılığıyla işlettiği güvenlik sisteminin düşük performansını rapor etti. Havalimanlarında yeni ve tecrübesiz özel güvenlik personel devrinin yüzde 400'den fazla olduğu, hatta özel güvenlik personelinin sadece \% 14'ünün 1 y1ldan fazla süredir çalıştığı belirtilmiştir. Yetersiz eğitim, düşük kalitede personel istihdamı, yüksek oranda personel değiştirme ve düşük ücretler hedeflenen güvenlik standardının yakalanamamasına sebep olmuştu.

11 Eylül 2001 acı olayları Federal Devlet'in taşımacılık sistemindeki derin güvenlik açığını ortaya koymuştu [36]. Federal devlet, 11 Eylül saldırıları ile güvenlik hizmeti almaktan vazgeçmiş, hizmeti bizzat kendisi verme kararı almıştır. ABD havacılık sistemi ve 11 Eylül saldırılarından sonra tespit edilen problemler, kamu güvenlik hizmetlerinin özelleștirilmesinde dikkat edilmesi gereken hususları somut bir şekilde göz önüne getirmektedir [44].

Hava meydanı güvenliğinde ve hava meydanındaki işletmelerin çalışmalarında insan faktörünün en öncelikli konu olduğunu söyleyebiliriz. Bu noktada güvenliği sağlayan özel güvenlik görevlilerinin, kolluk kuvvetlerinin, DHMİ havalimanları güvenlik memurlarının ve gümrük muhafaza memurlarının görevlerindeki verimliliğinin, sivil havacılık güvenliğinin etkinliğine (verimliliğine), doğrudan katkı sağladığı ve başarıyı arttırdığı görülmektedir.

\section{Tartışma ve Sonuç}

Güvenlik stratejileri ve yönetimi açısından sivil havacılık güvenliği devletlerin dünyaya karşı bir yüzünü oluşturmakta ve bu sahada oluşabilecek terör saldırıları gibi olumsuz durumlar ilgili ülkeye karşı ön yargıların oluşmasını da beraberinde getirmektedir. Tüm ülkeler için kritik öneme sahip sektörlerden biri olarak görülen havacılık; ortaya koyduğu gurur, saygınlık ve küresel ekonomik etkinin bir sonucu olarak ilgili ülkeler tarafindan ulusal bir sembol olarak görülmektedir [45]. Sivil havacılık faaliyetlerinde güvenliğin sağlanması uluslararası kurallara bağlanmıştır. Ancak ülkelerin bulunduğu coğrafi konum, komşuları ile olan ilişkileri ve terör eylemleri bakımından ses getirecek bir noktada olmaları gibi kendilerine özgü durumlarından dolayı, teknolojinin ve güvenliğin değişim yönüne göre sürekli güncellenen bir güvenlik stratejisi ve yönetimini zorunlu olarak hayata geçirmeleri gerekmektedir. $\mathrm{Bu}$ anlamda ülkelerin oluşturdukları olumlu sembol algısını yüksek tutabilmek ve teröristleri tüm bu havacıllk faaliyetleri alanlarından uzak tutmak adına, sivil havacılık faaliyetlerinde güvenliği sağlamak için her geçen gün yeni teknolojiler ve süreçler geliştirilmektedir. $\mathrm{Bu}$ teknolojilerin temel amacı havalimanı güvenlik süreçlerinde görevli personele karar alma ve uygulamalarda yardımcı olmaktır. Günümüz teknolojilerini kullanabilen iyi eğitilmiş ve motive olmuş güvenlik personeli havalimanlarında güvenliğin sağlanmasındaki temel unsurdur.

Havaalanlarında güvenlik zafiyetinin yaşanmaması için öncelikle güvenlik personelinin hataları en aza indirecek şekilde eğitim sürekliliğinin sağlanması gereklidir. Bunun yanında uygun teknolojilerin kullanılmasının ve süreç standartlarının havalimanı karakteristiğine uygun şekilde tasarlanmasının da önemli faktörler arasında olduğu görülmektedir.

Bunlarla birlikte havalimanlarında görev yapan koruma ve güvenlik memuru genel değil sadece kendisine tahsis edilen bölgenin ve eşyaların güvenliğinden, havalimanı yolcularının denetiminden sorumludur. $\mathrm{Bu}$ sorumluluk polislerde olduğu gibi örgüt (devlet) tarafından kendilerine güven duyulduğu algisı yaratarak işlerini toplum üzerinde 'kanuni yetkili' sıfatıyla yapmalarına imkân verirken, 'gücün temsilcisi' de olmaktadırlar. $\mathrm{Bu}$ da güvenlik memurlarının karşı1ıklı olarak örgüte güven duymalarını sağlayabilmektedir. Örgüte duyulan güven yüksek olursa daha başarılı ve yenilikçi bir örgüt olma özelliği ortaya çıkacağı [46] dile getirilmektedir. Çalışma sırasında irdelenen sivil havacilık güvenliğindeki kuramsal, hukuksal ve kurumsal değişimlerde göstermektedir ki sivil havacılık 
güvenliğinin sağlanmasının bir güvenlik stratejisi ve yönetiminin yanı sıra tüm sacayakları ile birlikte düşünüldüğünde örgütsel bir bağl1lığın ve bir güvenlik iklimi içerisinde güvenlik kültürünün de oluşturulması gerekliliğini kaçınılmazdır.

Diğer yandan "Havacılık güvenliği”" kapsamında yürütülen faaliyetler aynı zamanda havacılık emniyetini sağlamanın bir aracı olarak karşımıza çıkmaktadır. Çünkü isteyerek ya da istemeden insanların, sivil havacılık sistemindeki altyapının ve havaaraçlarının zarar görmesine sebep olabilecekleri herhangi bir riskin tanımlanması ve bunun kabul edilebilir seviyelere indirilmesi çok daha genel bir kavram olan "havacilık emniyeti" kapsamına girmektedir. Bununla birlikte, genellikle sivil havacılık alanında tanımlanan riskler kasıtlı ya da kasıtsız olmalarına göre sinıflandırılmakta ve kasitsız riskler "emniyet", kasitlı riskler ise "güvenlik" kapsamına alınmaktadır [30].

Tüm bunlarla birlikte havacılık sektöründe uluslararası standartlara uygun bir şekilde güvenlik hizmetlerinin sunumu, havacıllk sektörünün faaliyetlerini sürdürebilir kılmanın önemli adımı olmakla birlikte, sektörün son 50 yılda karşı karşıya kaldığı sorunların çözümüne de katk1 sağlamaktadır. 2016 yılında DAEŞ terör örgütü tarafindan Atatürk Havalimanı'nda gerçekleştirilen ve 42 kişinin hayatını kaybettiği, 238 kişinin ise yaralandığı terör saldırısı, bir kez daha havaalanlarının terör örgütleri için dikkat çeken noktalar olduğunu ve havaalanlarındaki güvenliğin önem derecesini göstermektedir. $\mathrm{Bu}$ anlamda güvenliğin sağlanması adına yerine getirilen tüm süreçlerde yaşanacak olumsuz durumlar, başta yolcular olmak üzere, süreçte yer alan tüm tarafların sıkıntı yaşamalarına, yaralanmalarına hatta hayatlarını kaybetmelerine neden olabilmektedir. Diğer yandan güvenliğin etkin bir biçimde sağlanamamas1, birçok örnekte olduğu gibi ölçülmesi mümkün olamayacak sonuçları ve ciddi maliyetleri de beraberinde getirmektedir.

Son olarak özellikle havacıllk sektörü için uçakta, uçuş sırasında, havalimanlarında ve kara tarafinda uluslararası standartlara uygun güvenlik hizmetinin verilebilmesinin, gelişen teknoloji ile birlikte gelişen ve değişen tehditlere karşı sürekli yenilenen, uluslararası düzenlemelere uygun bir güvenlik stratejisine ve yönetimine aynı zamanda kurumsal olarak güvenlik personelinin örgütsel bağının güçlü olmasına, yolcu ve tüm çalışanlarda bir güvenlik kültürü oluşturulmasına bağlı olduğu görülmektedir.

\section{Kaynaklar}

[1] SHGM, Emniyet Yönetim Sistemi Temel Esaslar, Ankara: Sivil Havacılık Genel Müdürlüğü, Yayın No: HAD/T-18, 2012.

[2] H. G. Brauch, "Güvenliğin Yeniden Kavramsallaştırılması: Barış, Güvenlik, Kalkınma ve Çevre Kavramsal Dörtlüsü”, Uluslararası İlişkiler Dergisi, 5(18), 1-47. 2008.

[3] Z. Çalık,H. Çomak ve A. G. Kutlu (Ed.), "Yeni Güvenlik Kavramı," Uluslararası Güvenlik Kongresi, Kocaeli Üniversitesi Yayınları, 638645. 2014.

[4] H. G. Brauch, H. G. Brauch, H. P. Liotta, A. Marquina, F. P. Rogers, ve S. M. El-Sayed (Ed.), Security and Environment Linkages on the Mediterranean Space: Three Phases of Research on Human and Environmental Security and Peace, New York: SpringerVerlag, 2003.

[5] M. Cabric, Corporate Security Management Challenges, Risks, and Strategies, Massachusetts: Elsevier Inc., 2015.

[6] B. Dedeoğlu, Uluslararası Güvenlik ve Strateji, İstanbul: Yeniyüzyıl Yayınları, 2008.

[7] E. Rothschild, B. Buzan ve L. Hansen (Ed.), What is Security, London: Sage Publications Ltd., 2007.

[8] E. Çıtak, E. Çıtak ve O. Şen (Ed.), "Yeni Gerçekçilik ve Güvenlik," Uluslararası İlişkilerde Güvenlik Teorik Değerlendirmeler, 33-46. 2014.

[9] M. Şöhret, H. Çomak ve A. G. Kutlu (Ed.), "Kopenhag ve Aberystwyth Ekolleri Çerçevesinde 21. Yüzyılda Güvenliğin Değişen Kapsamı ve Boyutu," Uluslararası 
Güvenlik Kongresi, Kocaeli: Kocaeli Üniversitesi Yayınları, 638-645. 2014.

[10] K. Booth, Dünya Güvenliği Kuramı, Ç. Üngör (çev.), İstanbul: Vefa Yayınları. 2007.

[11] K. Booth, "Security and Emancipation", Review of International Studies, 17(4), 313326. 1991.

[12] O. Waever, "Security", Encyclopedia of Global Studies, C. 4, Thousand Oaks, Calif: SAGE Publications Inc., 2012.

[13] B. Buzan, People, States, and Fear The National Security Problem in International Relations, Sussex: Wheatsheaf Books Ltd., 1983.

[14] İ. Erdoğan, "Küreselleşme Olgusu Bağlamında Yeni Güvenlik Algısı", Akademik Bakış, 6(12), 265-292. 2013.

[15] O. Waever; T. Flockhart (Ed.), "Cooperative Security: A New Concept?," DIIS Report 2014:01, Copenhagen: Danish Institute For International Studies, 47-59. 2014.

[16] P. D. Williams, Security Studies: An Introduction, New York: Routledge. 2008.

[17] S. Malik; P. Hough, S. Malik, A. Moran ve B. Pilbeam (Ed.), International Security Studies Theory and Practice, New York: Routledge, 2015.

[18] J. Baylis, "Uluslararası İlişkilerde Güvenlik Kavramı," Uluslararası İlișkiler, 5(18), 69-85. 2008.

[19] H. Çomak, “Avrupa Güvenlik Yapılanmasının Yeni Parametreleri ve Türkiye'nin Durumu," 1-14. 2008.

http://www.bilgesam.org/incele/829/-avrupaguvenlik-yapilanmasinin-yeni-parametrelerive-turkiye\%27nin-durumu/\#.WSBu8uvyjDc [Erişim Tarihi: 15.04.2017].

[20] H. Akyıldız, "Globalleşme Sürecinde Uluslararası Güvenlik Antlaşmalarının Yönü ve Türkiye'nin Geleceği," Süleyman Demirel
Üniversitesi, Sosyal Bilimler Enstitüsü, Yüksek Lisans Tezi, 2002.

[21] B. Kılıç, "Soğuk Savaş Sonrası Nato'nun Dönüşümü," Atılım Üniversitesi, Sosyal Bilimler Enstitüsü, Yüksek Lisans Tezi, 2010.

[22] R. P. Faber, NATO's Military Transfomation Past, Present, Future, Roma: NATO Defence College Occasional Paper, 2004.

[23] A. Sandıklı, Teoriler Işıı̆ında Güvenlik, Savaş, Barış ve Çatışma Çözümleri, İstanbul: Bilge Adamlar Stratejik Araştırmalar Merkezi Yayınları, 2012.

[24] ICAO, "Annual Report 2017 / The World of Air Transport in 2017." https://www.icao.int/annual-report2017/Pages/the-world-of-air-transport-in2017.aspx [Erişim Tarihi: 12 Şubat 2019].

[25] K. Button, "The Impacts of Globalisation on International Air Transport Activity." OECD/ITF Global Forum on Transport and Environment in a Globalising World. 1-40. http://www.oecd.org/greengrowth/greeningtransport/41373470.pdf [Erişim Tarihi: 10 Aralık 2018].

[26] IATA, “Annual Review 2015." https://www.iata.org/about/Documents/iataannual-review-2015.pdf [Erişim Tarihi: 12 Şubat 2019].

[27] DHMİ, "Havacılık Güvenliği Eğitmen El Kitabı."

https://www.dhmi.gov.tr/Lists/DosyaYonetim iList/Attachments/270/HavacilikGuvenligiEgi tmenElKitabi.pdf [Erișim Tarihi: 12 Şubat 2019].

[28] IATA, "IATA Annual Review." https://www.iata.org/publications/Documents/ iata-annual-review-2017.pdf [Erişim Tarihi: 12 Șubat 2019].

[29] ICAO, Annex-17 to the Convention on International Civil Aviation: International Standards and Recommended Practices Security Safeguarding International Civil 
Aviation Against Acts of Unlawful Interference, Montreal: ICAO, 1997.

[30] E. Gerede, "Havacılık Emniyeti ve Havacılık Güvenliği Kavramları Arasındaki İlişki ve Farkların Belirlenmesine Yönelik Bir Araştırma," Yönetim, 17(54), 26-37. 2006.

[31] M. Milde, International Air Law and ICAO. Netherlands: Eleven International Publishing, 2012.

[32] C. Bala, "Aviation Security: Proactive or Playing Catch-up,"

http://www.saa.com.sg/saaWeb2011/export/si tes/saa/en/About_Us/downloads/Aviation_Sec urity Proactive Playing Catch up.pdf

[Erişim Tarihi: 17.05.2017].

[33] H. Andriessen, V. C. Gulijk ve B. Ale, "Human Factors In Layers Of Defense In Airport Security," Safety Science Group, Delft University of Technology, 1-8. 2012.

[34] B. Elias, "National Aviation Security Policy, Strategy and Mode-Specific Plans: Background and Considerations for Congress," Congressional Research Service, https://fas.org/sgp/crs/homesec/RL34302.pdf [Erişim Tarihi: 18.05.2017].

[35] W. D. Freer, "Maturity Brings New Challenges-1957 to 1976," ICAO Bulletin, Official Mangazine of International Civil Aviation, 41(12), 24-26. 1986.

[36] P. S. Dempsey, Public International Air Law, Montreal: McGill University, 2008.

[37] S. Ünlü, "11 Eylül Olaylarının Uluslararası Sivil Havacılık Güvenliğine Etkileri," Selçuk Üniversitesi, Sosyal Bilimler Enstitüsü, Yüksek Lisans Tezi, 2009.

[38] A. K. Sayın, "Sivil Havacılık Güvenliğinde Özel Güvenlik Hizmetlerinin Etkinliğinin İncelenmesi, Esenboğa Havalimanı Örneği," Polis Akademisi, Güvenlik Bilimleri Enstitüsü, Yüksek Lisans Tezi, 2011.

[39] A. Uzuner, Sivil Havacılık Güvenliği, Ankara: Özen Yayımc1lık, 2003.

[40] A. K. Sayın, "Havalimanı Güvenliği Alanında Özel Güvenlik Hizmetlerinin Sorunları ve
Çözüm Önerileri; Malatya Havalimanı Örneği,” 3. Ulusal Özel Güvenlik Sempozyumu, 123-132. 2013.

[41] H. Küçükönal, "Havaalanı Güvenliği ve Sabiha Gökçen Uluslararası Havaalanı Güvenlik Sistemi İçin Bir Model Önerisi," Anadolu Üniversitesi, Sosyal Bilimler Enstitüsü, Doktora Tezi, 2001.

[42] A. Kirschenbaum, M. Mariani, V. C. Gulijk, C. Rapaport ve S. Lubasz, "Trusting Technology: Security Decision Making at Airports," Journal of Air Transport Management, 25, 57-60. 2012.

[43] H. Doğan, Hulusi, "İş görenlerin Adalet Algılamalarında Örgüt İçi İletişim ve Prosedürel Bilgilendirmenin Rolü," Ege Üniversitesi, Akademik Bakıș Dergisi, 2(2), 69-76. 2004.

[44] Y. Uryan ve A. Kapt1, "Güvenlik Hizmetlerinde Devlet-Özel Sektör İşbirliği: Metodoloji ve Kriterler," Polis Bilimleri Dergisi, 13(1), 156-176. 2011.

[45] C. A. Korkmaz ve E. Bütün, "Havacilık Güvenliğinde Güvenlik Mülakatı Uygulamas1," Journal of Aviation, 2(1), 56-63. 2018.

[46] İ. K. Tüzün, "Güven, Örgütsel Güven ve Örgütsel Güven Modelleri," Karamanoğlu Mehmetbey Üniversitesi Sosyal ve Ekonomik Araştırmalar Dergisi, (2), 93-118. 2007. 